\title{
Role of biomedical and behavioral interventions and their evidence in prevention of HIV infection: A literature review
}

\section{Vijay Kumar Chattu}

MPhil - Researcher, Africa Center for HIVIAIDS Management, University of Stellenbosch, Matieland, Stellenbosch, South Africa

Address for the Correspondence: Dr. Vijay Kumar Chattu, Department of Community Medicine, Dr. SMCSI Medical College and Hospital, Karakonam

(PO), Trivandrum - 695504 Kerala, India

E-mail: drvkumar.ch@gmail.com

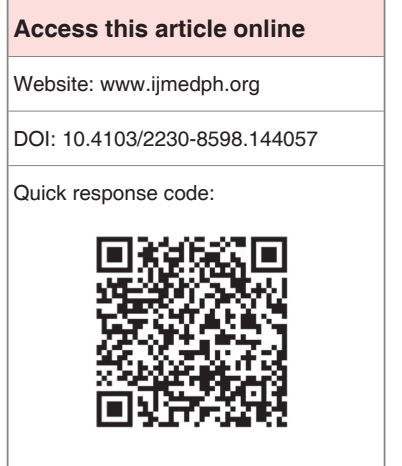

Around 2.5 million people become infected with HIV each year and after 30 years of the HIV epidemic more than 34 million persons are living with HIV infection. This extraordinary toll on human life and public health worldwide will only be reversed with effective prevention. There is a need for evidence-based interventions that can be implemented to treat the established infections and prevent the new ones from happening. This paper aims to discuss about different types of HIV prevention strategies that are effective and practiced in different countries with special emphasis on evidence for success. A review of the literature was done to get the information about the successful interventions for HIV prevention from different countries. The literature was accessed from health and medical sciences databases available on the internet. All the relevant peer-reviewed journals and reports were studied and were categorically discussed in detail with the evidence. For a successful reduction in HIV transmission, there is a need for an aggregate effect of radical and sustained behavioral changes in a sufficient number of individuals potentially at risk. Reductions in HIV transmission need widespread and sustained efforts, and a mix of communication channels to disseminate messages to motivate people to engage in range of options to reduce the risk. The effect of behavioral strategies could be increased by aiming for many goals that are achieved by use of multilevel approaches with populations both uninfected and infected with HIV. These prevention programs operate on different levels to address the specific, but diverse needs of the populations at risk of HIV infection. There is an urgent need for greater demand and greater support from communities and policymakers for rights-based, evidenceinformed prevention strategies. And the prevention experts need to overcome the prejudices and political sensitivities that have impeded implementation of the HIV prevention programs

Key words: Behavioral strategies, biomedical interventions, communication, HIV/AIDS, prevention

\section{INTRODUCTION}

Around 2.5 million people become infected with HIV each year and after 30 years of the HIV epidemic more than 34 million persons are living with HIV infection. This extraordinary toll on human life and public health worldwide will only be reversed with effective prevention. There is a need for evidence-based interventions that can be implemented to treat the established infections and prevent the new ones from happening. The role of biomedical and behavioral interventions is found to be very effective in a reduction of the new infections. These strategies or interventions must be based on scientifically derived evidence, with input and engagement from local communities that fosters the successful integration of care and treatment. These prevention programs or interventions can operate on different levels such as individual, relationship, community, societal to address the specific, but diverse needs of the populations at risk of HIV infection.

The UNAIDS Prevention Reference Group agreed in December, 2009 that combination prevention programs are. 
Rights-based, evidence-informed, and community-owned programs that use a mix of biomedical, behavioral, and structural interventions, prioritized to meet the current HIV prevention needs of particular individuals and communities, so as to have the greatest sustained impact on reducing new infections.

\section{BEHAVIOURAL STRATEGIES}

They are defined as "interventions to motivate behavioral change in individuals and social units by use of a range of educational, motivational, peer-led, skill-building approaches as well as community normative approaches" (Coates and Gable 2008).

They include the sexual debut delay, sexual partner reduction, Consistent condom usage, HIV counseling and testing, sexual abstinence, monogamy, biomedical intervention uptake and consistent usage, adherence to harm reduction strategies. Behavioral interventions fall into two broad categories.

\section{Interventions to minimize sexual risk behaviors/ increase protective behaviors \\ Evidence}

They include sexual behavior change communications (SBCC) that employ a variety of channels to communicate a range of messages. Studies have been undertaken to assess both channels of communication and the content of the messages.

\section{Channels of communication Mass media}

Much of the research on mass media has focused on changes in intermediary indicators such as knowledge, risk perception, and self-efficacy. Reviews of this research have generally found small, but positive effects on each of these indicators. ${ }^{[1]}$ Studies have also linked mass media to reported positive behavioral outcomes such as delay of sexual debut, ${ }^{[2]}$ decreases in a number of sexual partners, ${ }^{[3-5]}$ increases in condom use ${ }^{[6-8]}$ and utilization of high throughput computing (HTC) and prevention of mother-to-child transmission services. ${ }^{[9,10]}$ Current research suggests that mass media is most effective when used to: Facilitate advocacy efforts ${ }^{[1]}$ and complement other community-level and interpersonal activities. Mass media programming has been shown to produce a dose-response effect, in which higher exposure to messaging resulted in increased selfreported positive behavioral change. ${ }^{[12]}$

\section{Community-level interventions}

Community mobilization campaigns have been shown to increase uptake of HTC in discordant couples ${ }^{[13]}$ and youth. ${ }^{[14]}$ Specific activities such as community-based dramas have been shown to increase HTC utilization and condom use. ${ }^{[15]}$ Locally-based media programs have been shown to impact social norms, including perceptions of HIV-positive individuals. ${ }^{[16]}$ While their geographic reach is often limited, effective community-based activities generally provide good results at a low cost per beneficiary, although the duration of these effects is unknown. ${ }^{[17]}$ Communitylevel activities are most effective when they: Focus explicitly on community norms; develop key opinion leaders with the abilities and desire to diffuse messages widely, and facilitate support systems and networks. ${ }^{[18]}$

\section{Interpersonal communication}

Interpersonal communication and counseling are defined as personto-person or small group interaction and exchange. ${ }^{[19,20]}$ A recent meta-analysis of research examining interpersonal communication found that the exposure was significantly associated with increased knowledge and condom use. ${ }^{[21]}$ In addition to these outcomes, peer education has demonstrated some success in changing community attitudes and norms. ${ }^{[2]}$ Cost-effectiveness studies have shown that interpersonal communication has the ability to reach hard-to-reach population groups in a cost-effective manner. ${ }^{[23]}$

\section{Focus of messages \\ Multiple partnerships}

Sexual activity with more than one partner plays a central role in all sexually-driven HIV epidemics. Ecological and associational evidence from generalized and concentrated epidemics points to a consistent pattern of significant decline in the proportion of men and women reporting multiple partners, followed by population-level declines in HIV infection. ${ }^{[24-26]}$ Behavioral interventions utilizing various communication channels have had a demonstrable impact on reducing numbers of sexual partners in numerous populations including MSM, adult men and women, and young people. ${ }^{[27,28]}$ While debate exists around the role of concurrent, as opposed to sequential, partnerships in HIV transmission, ${ }^{[29]}$ efforts to evaluate concurrency reduction interventions are on-going. ${ }^{[30]}$

\section{Intergenerational and transactional sex}

In many settings, intergenerational sex and transactional sex are closely related. ${ }^{[31,32]}$ Both practices are driven by economic needs or wants, as well as deeply-entrenched norms supporting age differences between partners and male dominance in relationships. ${ }^{[33]}$ Women's ability to refuse sex or negotiate condom use, which may already be limited, may be further compromised by age differences between partners or exchange of money or gifts. These factors, in combination with young women's biological vulnerability to HIV infection, contribute to heightened risk for both young women and their male partners. ${ }^{[34]}$

\section{Age of sexual debut}

A number of national population-based surveys ${ }^{[35,36]}$ have found a correlation between early initiation of sex and higher HIV prevalence among young people. Increased mean age of sexual debut is thought to be one contributing factor in declining HIV prevalence in some generalized epidemics in sub-Saharan Africa. ${ }^{[37]} \mathrm{A}$ multicountry study of youth in sub-Saharan Africa found that programs promoting abstinence, including those utilizing mass media, could produce increases of up to one year in mean age of sexual debut. ${ }^{[38]}$

\section{Alcohol use}

Alcohol use plays a critical role in sexual risk behavior that can lead to HIV transmission. Multiple studies have found that persons who 
use alcohol in sexual situations are more likely to have unprotected sex, casual sex, and multiple partners, than persons who do not use alcohol in sexual situations. ${ }^{[39]}$ Alcohol consumption is linked with increased risk of sexually transmitted infection (STI) and HIV infection, ${ }^{[40]}$ gender-based violence and nonadherence to antiretroviral therapy (ART).

\section{Supportive interventions to optimize biomedical interventions by creating demand for services and improve adherence and aftercare. Creating demand for services Evidence}

Sexual behavior change communications has been widely used over the past decade to create demand for biomedical prevention approaches, including HTC and voluntary medical male circumcision (VMMC). HTC-focused mass media campaigns in Kenya and South Africa have been shown to increase uptake of testing services, with clear dose-response effects. ${ }^{[41,42]}$ Evidence from South Africa further indicates that exposure to SBCC programs is associated with discussing HIV and that discussion of HIV is associated with testing — suggesting a possible indirect effect of HTC promotion interventions. ${ }^{[43,44]}$

\section{Improving adherence and aftercare through client education Evidence}

Creating demand for services, while essential, is not sufficient in isolation to ensure positive outcomes. Helping clients identify side effects and adverse events, take medication correctly, and care for themselves following medical procedures can all contribute to optimal use of medical technologies. A randomized control trial in Kenya found that SMS reminders significantly improved ART adherence among patients. ${ }^{[45]}$ Similar approaches have been used to support attendance at VMMC follow-up visits.

\section{Biomedical interventions}

Defined as the "interventions are those that act directly on the biological systems through which the virus infects a new host." Some of the biomedical interventions include:

1. Male condoms: When used consistently and correctly, male latex condoms are highly effective in preventing the sexual transmission and acquisition of HIV and other STIs at the individual level. ${ }^{[46,47]}$ Among most-at-risk populations, increasing condom availability, accessibility, acceptability, and use has had a demonstrable population-level effect in several epidemics. ${ }^{[48,49]}$ In heterosexual serodiscordant relationships in which condoms were consistently used, HIV-negative partners were $80 \%$ less likely to become infected compared with persons in similar relationships in which condoms were not used. ${ }^{[50]}$

2. Female condoms: Laboratory studies indicate that the female condom (FC2) is an effective mechanical barrier to semen and viruses, including HIV. ${ }^{[1]}$ In 2006, WHO concluded that female condoms, when used consistently and correctly, have comparable effectiveness to male condoms. In 2009, the Food and Drug Administration approved the second generation of the FC2 for prevention of HIV, other STIs, and unintended pregnancy. A growing body of evidence shows that effective FC2promotion to both women and men can increase the proportion of protected sex acts. ${ }^{[52-54]}$ Studies conducted in a variety of contexts show that the FC2is widely acceptable and realistic alternative to the male condom. ${ }^{[55]}$

3. Voluntary medical male circumcision: Voluntary medical male circumcision is the surgical removal of the foreskin from the penis by trained medical personnel under aseptic conditions. Three randomized control trials indicated that VMMC reduces men's risk of HIV acquisition by $50-60 \% .^{[56-58]}$ Extended follow-up of participants at up to 5 years posttrial indicated that the protective effect increased to $68 \% .{ }^{[59]}$ WHO and UNAIDS have concluded that VMMC should be actively promoted as part of comprehensive HIV prevention efforts in settings where circumcision rates are low, and HIV prevalence is high. ${ }^{[60]}$ A prospective study enrolling HIV sero-discordant couples found a promising, although not statistically significant, $40 \%$ reduction in sero-conversions of women whose male partners were circumcised. ${ }^{[61]}$ A recent study suggests that VMMC, with the life-long protection it provides, is a cost-effective strategy to prevent HIV in highprevalence areas. ${ }^{[62]}$

4. HIV testing and counseling (high throughput computing): The evidence for the direct impact of HIV testing and counseling on HIV incidence is mixed. However, HTC, knowledge of HIV sero-status, and successful linkages to other services are critical for access to effective prevention interventions for those who test negative, and to treatment and other HIV-specific services for people living with HIV/AIDS (PLWH). In particular, HTC process allows for identification of PLWH, which in turn supports programs like treatment that can protect their HIV-negative partners from infection. ${ }^{[63]}$ Recent Demographic and Health Surveys from 13 sub-Saharan African and five nonAfrican countries show a median of $12 \%$ of women and $7 \%$ of men having been tested in the 12 months preceding the survey, and a median of $34 \%$ of women and $17 \%$ of men reporting having ever been tested.

5. Diagnosis and treatment of sexually transmitted infections.

6. Studies have shown that STIs, including those that are asymptomatic, increase susceptibility to HIV infection twoto five-fold for several reasons, including direct damage to the mucosa through ulceration that facilitates infection, and through inflammatory processes that increase the proliferation of immune cells that are also targets for HIV. ${ }^{[64,65]}$ STIs also lead to higher HIV loads in the genital secretions of HIV-positive individuals, thereby increasing the chance of infecting their sexual partners. ${ }^{[66]}$ STIs are biological markers for risky sexual behaviors, increase susceptibility to HIV acquisition through genital ulcers, and increase onward transmission of HIV associated with HIV viral spikes. ${ }^{[67-69]}$ 
7. Antiretroviral drug-based prevention: There are four opportunities for HIV prevention: Before exposure, at the moment of exposure, immediately after exposure, and as prevention focused on infected persons. Until recently, most prevention resources have been directed toward strategies aimed at preventing exposure. There is growing evidence that ART of infected individuals has an added prevention benefit. Treatment of HIV and prevention of HIV must be considered as elements of a single continuum and deployed together.

\section{Postexposure prophylaxis for HIV}

Postexposure prophylaxis (PEP) refers to the set of services that are provided to manage specific aspects of exposure to HIV and to help prevent HIV infection in a person exposed to the risk of infection. These services might include first aid, counseling including assessing the risk of HIV exposure, HTC, and depending on the outcome of exposure assessment, a limited course of antiretroviral drugs (ARVs), with appropriate support and follow-up.

\section{Evidence}

Strong evidence suggests that a short course of ARVs started within $72 \mathrm{~h}$ after exposure effectively reduces HIV transmission rates following needle stick exposure to HIV-infected blood. This comes largely from a single-case control study involving health care workers from France, UK and USA that revealed strong inverse associations between the likelihood of HIV infection following a needlestick injury and the postexposure use of zidovudine. ${ }^{[70]}$ However, data available from animal transmission models, ${ }^{[71]}$ perinatal clinical trials, ${ }^{[72]}$ studies of health-care workers receiving prophylaxis after occupational exposures, ${ }^{[73]}$ and observational studies ${ }^{[74]}$ indicate that PEP may reduce the risk of HIV infection after nonoccupational exposures as well.

\section{Treatment as prevention \\ Evidence}

An important determinant of risk of HIV transmission from an HIVpositive person to an HIV-negative person is the concentration of HIV in plasma. ART for the HIV-positive partner is associated with both reduced viral load ${ }^{[75,76]}$ and reduced risk of HIV transmission to sex partners within discordant partnerships, potentially by over $90 \% .{ }^{[77-80]}$ These observational data were recently confirmed by HPTN 052, a randomized trial among 1,763 HIV sero-discordant couples in which the HIV-positive partner had a CD4 count between 350 and 550 cells $/ \mu \mathrm{L}$. The trial evaluated the effect of immediate versus delayed ART (initiated at CD4 of 250 cells/ $\mu \mathrm{L}$ ) in an HIVpositive individual.

\section{Pre-exposure prophylaxis for HIV Evidence}

In the CAPRISA 004 study in South Africa, 889 high-risk women used $1 \%$ tenofovir gel vaginally up to $12 \mathrm{~h}$ before intercourse and within $12 \mathrm{~h}$ after intercourse. ${ }^{[81]}$ This study reported a 39\% reduction in HIV acquisition overall, and maximal reduction of $54 \%$ in women who were the most adherent. HIV acquisition was inversely correlated with detection of tenofovir in the vaginal secretions, an indication of the strong association between product adherence and efficacy.

In the iPrEx study completed in 2010, ${ }^{[82]}$ HIV-negative MSM were provided daily emtricitabine and tenofivir disoproxilfumarate (TDF + FTC) for up to 2.8 years. The study found $44 \%$ reduction in HIV acquisition, and as with the CAPRISA trial, efficacy was strongly associated with ARV drug concentrations.

Another study, conducted by CDC in partnership with Botswana Ministry of Health, found that a once-daily tablet containing TDF+FTC reduced the risk of acquiring HIV infection by roughly $63 \%$ overall in the study population of uninfected heterosexual men and women. ${ }^{[83]}$

\section{CONCLUSIONS}

All the different strategies and interventions were discussed in detail in the respective paragraphs above with evidence from various research project sites/trials thereby providing a strong support for decision making for public health professionals \& clinicians. As public health professionals we must agree with the evidence-based medicine and have to find the lacunae in our implementing programs and correct the gaps for effective prevention using the combination of these biomedical and behavioral interventions that are implemented cost effectively among the high-risk groups as well to halt the epidemic. These prevention strategies remind us that successful programs deal with both individual risk and underlying causes of vulnerability. They require biomedical and behavioral interventions that are specifically selected and tailored to suit local needs as articulated by affected communities.

Prevention is much easier and better than cure, especially for HIV infection. There is an urgent need for greater demand and greater support from communities and policymakers for rights-based, evidence-informed prevention strategies. To build this support, prevention experts need to speak with one voice, responding in real time with strategic advocacy to overcome the prejudices and political sensitivities that have often impeded implementation of the programs most likely to reduce HIV incidence. Effective implementation of this type of combined prevention strategies requires sufficient personnel to define and tailor programs at the sub-national level, to synthesize available evidence, to manage multicomponent programs for specific results. Quality assurance and quality improvement are very important in behavioral and biomedical interventions ones. And to succeed, these must be coordinated, efficient, consistent, and inspired by a shared commitment to common goals.

\section{ACKNOWLEDGMENT}

The researcher thanks the Director and staff of Africa center for HIV/ AIDS Management, for their continuous encouragement \& support. The 
author also acknowledges the great help received from the scholars whose articles cited and included in references of this manuscript. The researcher is also grateful to authors/editors/publishers of all those articles, journals and books from where the literature for this article has been reviewed and discussed. The author is grateful to the editorial board members and team of reviewers who have helped to bring quality to this manuscript.

\section{REFERENCES}

1. Bertrand JT, O'Reilly K, Denison J, Anhang R, Sweat M. Systematic review of the effectiveness of mass communication programs to change HIVIAIDS-related behaviors in developing countries. Health Educ Res 2006;21:567-97.

2. FHI. Abstinence, fewer partners\& condom use are complementary messages. Arlington, FHI. 2003 BMC Public Health 2011;11:304.

3. Noar SM. A 10-year retrospective of research in health mass media campaigns: Where do we go from here? J Health Commun 2006;11: 21-42.

4. Snyder LB, Huedo-Medina TB, et al. Effectiveness of media interventions to prevent HIV transmission, 1986-2006: A meta-analysis. In Review. http:// pdf.usaid.gov/pdf_docs/PCAAC329.pdf [Last accessed on 2014 Apr 25].

5. Vaughan PW, Rogers EM, Singhal A, Swalehe RM. Entertainmenteducation and HIVIAIDS prevention: A field experiment in Tanzania. J Health Commun 2000;5 Suppl:81-100.

6. Wakefield MA, Loken B, Hornik RC. Use of mass media campaigns to change health behaviour. Lancet 2010;376:1261-71.

7. Bertrand JT, O'Reilly K, Denison J, Anhang R, Sweat M. Systematic review of the effectiveness of mass communication programs to change HIVIAIDS-related behaviors in developing countries. Health Educ Res 2006;21:567-97.

8. Noar SM, Carlyle K, Cole C. Why communication is crucial: Meta-analysis of the relationship between safer sexual communication and condom use. $J$ Health Commun 2006;11:365-90.

9. Marum E, Morgan G, Hightower A, Ngare C, Taegtmeyer M. Using mass media campaigns to promote voluntary counseling and HIV-testing services in Kenya. AIDS 2008;22:2019-24.

10. Sebert Kuhlmann AK, Kraft JM, Galavotti C, Creek TL, Mooki M, Ntumy R. Radio role models for the prevention of mother-to-child transmission of HIV and HIV testing among pregnant women in Botswana. Health Promot Int 2008;23:260-8.

11. Abroms LC, Maibach EW. The effectiveness of mass communication to change public behavior. Annu Rev Public Health 2008;29:219-34.

12. Van Rossem R, Meekers $\mathrm{D}$. The reach and impact of social marketing and reproductive health communication campaigns in Zambia. BMC Public Health 2007;7:352.

13. Chomba E, Allen S, Kanweka W, Tichacek A, Cox G, Shutes E, et al. Evolution of couples' voluntary counseling and testing for HIV in Lusaka, Zambia. J Acquir Immune Defic Syndr 2008;47:108-15.

14. Ngubane T. Innovative mobilization strategies for attracting at risk youth and young adults to participate in community-based voluntary counseling and testing in rural Kwa-Zulu Natal, South Africa (Project AcceptHPTN 043). XVII International AIDS Conference, August 3-8, 2008. Mexico City, Mexico.

15. Harvey B, Stuart J, Swan T. Evaluation of a drama-in-education programme to increase AIDS awareness in South African high schools: A randomized community intervention trial. Int J STD AIDS 2000;11:105-11.

16. Goldstein S, Usdin S, Scheepers E, Japhet G. Communicating HIV and AIDS, what works? A report on the impact evaluation of Soul City's fourth series. J Health Commun 2005;10:465-83.

17. Donahue J, Williamson J. Community mobilization to mitigate HIVIAIDS. Report prepared by the Displaced Children and Orphans Fund and War Victims Fund Project for the United States Agency for International Development. 1999 (http://pdf.usaid.gov/pdf_docs/Pnacm936.pdf) [Last accessed on 2014 Apr 25].

18. Khumalo-Sakutukwa G, Morin SF, Fritz K, Charlebois ED, van Rooyen $\mathrm{H}$, Chingono A, et al. Project Accept (HPTN 043): A community-based intervention to reduce HIV incidence in populations at risk for HIV in subSaharan Africa and Thailand. J Acquir Immune Defic Syndr 2008;49: 422-31.
19. Aggleton P. Behavior change communication strategies. AIDS Educ Prev 1997;9:111-23.

20. AED Center for Global Health and Communication Marketing. Accessible at: http://www.globalhealthcommunication.org/strategies/interpersonal_ communication_counseling [Last accessed on 2014 Apr 25].

21. Medley A, Kennedy C, O'Reilly K, Sweat M. Effectiveness of peer education interventions for HIV prevention in developing countries: A systematic review and meta-analysis. AIDS Educ Prev 2009;21: 181-206.

22. Maticka-Tyndale E, Barnett JP. Peer-led interventions to reduce HIV risk of youth: A review. Eval Program Plann 2010;33:98-112.

23. Fung IC, Guinness L, Vickerman P, Watts C, Vannela G, Vadhvana J, et al. Modelling the impact and cost-effectiveness of the HIV intervention programme amongst commercial sex workers in Ahmedabad, Gujarat, India. BMC Public Health 2007;7:195.

24. Green EC, Mah TL, Ruark A, Hearst N. A framework of sexual partnerships: Risks and implications for HIV prevention in Africa. Stud Fam Plann 2009;40:63-70.

25. Shelton JD. Why multiple sexual partners? Lancet 2009 1;374:367-9.

26. Mishra V, Hong R, Bignami-Van Assche S. The role of partner reduction and faithfulness in HIV prevention in sub-Saharan Africa: Evidence from Cameroon, Rwanda, Uganda, and Zimbabwe. DHS Working Papers No. 61. Calverton, Maryland, Demographic and Health Research Division, Macro International Inc. 2009; (http://pdf.usaid.gov/pdf_docs/PNADO191. pdf) [Last accessed on 2014 Apr 25].

27. Herbst JH, Sherba RT, Crepaz N, Deluca JB, Zohrabyan L, Stall RD, et al. A meta-analytic review of HIV behavioral interventions for reducing sexual risk behavior of men who have sex with men. J Acquir Immune Defic Syndr 2005;39:228-41.

28. Noar SM. Behavioral interventions to reduce HIV-related sexual risk behavior: Review and synthesis of meta-analytic evidence. AIDS Behav 2008;12:335-53.

29. World Bank, USAID. World Bank debate series: Debate 4. Concurrent sexualpartnerships. 2010 http://siteresources.worldbank.org/INTHIVAIDS/ Resources/375798-1297872065987/Debate4SUMMARY ConcurrentSexual Partnerships.pdf. [Last accessed on 2011 Jun 17]

30. Tanser F, Bärnighausen T, Hund L, Garnett GP, McGrath N, Newell ML. Effect of concurrent sexual partnerships on rate of new HIV infections in a high-prevalence, rural South African population: A cohort study. Lancet 2011;378:247-55.

31. Hawkins K, Price N, Mussa F. Milking the cow: Young women's construction of identity and risk in age-disparate transactional sexual relationships in Maputo, Mozambique. Glob Public Health 2009;4:169-82.

32. Luke N, Kurz K. Cross-generational and Transactional Sexual Relations in Sub-Saharan Africa: Prevalence of Behavior and Implications for Negotiating Safer Sexual Practices, Population Services International and International Center for Research on Women. Washington, DC AIDSMARK Reoprt 2002; [http://allafrica.com/healthafrica/cca/resources/ view/00010860.pdf] [Last accessed on 2014 Apr 25]

33. Dunkle KL, Jewkes RK, Brown HC, Gray GE, Mclntryre JA, Harlow SD. Transactional sex among women in Soweto, South Africa: Prevalence, risk factors and association with HIV infection. Soc Sci Med 2004;59:1581-92.

34. Leclerc-Madlala S. Age-disparate and intergenerational sex in southern Africa: The dynamics of hypervulnerability. AIDS 2008;22 Suppl 4: S17-25.

35. Munjoma MW, Mhlanga FG, Mapingure MP, Kurewa EN, Mashavave GV, Chirenje MZ, et al. The incidence of HIV among women recruited during late pregnancy and followed up for six years after childbirth in Zimbabwe. BMC Public Health 2010;10:668.

36. Busza JR, Balakireva OM. Street-based adolescents at high risk of HIV in Ukraine. Journal of Epidemiol and Comm Health, J Epidemiol Comm Health 2010. (http://jech.bmj.com/content/early/2010/09/23/ jech.2009.097469.full.pdf+html) [Last accessed on 2014 Apr 25].

37. Bessinger R, Akwara P, Halperin DT. Sexual behavior, HIV, and fertility trends: A comparative analysis of six countries. Chapel Hill, MEASURE Evaluation Project. Phase I of ABC study 2003; (http://www.cpc.unc.edu/ measure/publications/special/abc.pdf) [Last accessed on 2014 Apr 25].

38. FHI. Abstinence, fewer partners and condom use are complementary messages. Arlington, FHI. 2003 https://www.iywg.org/sites/iywg/files/ yl8e.pdf [Last accessed on 2014 Apr 25]. 
39. Kalichman SC, Simbayi LC, Vermaak R, Cain D, Jooste S, Peltzer K. HIVIAIDS risk reduction counseling for alcohol using sexually transmitted infections clinic patients in Cape Town, South Africa. J Acquir Immune Defic Syndr 2007;44:594-600.

40. $\mathrm{Li} \mathrm{Q}, \mathrm{Li}$ X, Stanton B. Alcohol use among female sex workers and male clients: An integrative review of global literature. Alcohol Alcohol 2010;45:188-99.

41. Marum E, G. Morgan. Using mass media campaigns to promote voluntary counseling and HIV-testing services in Kenya. AIDS 2008;22:2019-24

42. Kincaid L. AIDS communication programs, HIV prevention, and living with HIVIAIDS in South Africa. Pretoria, JHHESA.(jhhesa.org/sites/default/files/ pdfs/23_National_HIV_and_AIDS.pdf) [Last accessed on 2014 Apr 25].

43. Gay J, Hardee K, Croce-Galis M. What works for women and girls: Evidence for HIVIAIDS interventions. New York: Open Society Institute; 2010. p. 530 (http://www.popline.org/node/217238) [Last accessed on 2014 Apr 25].

44. Johnson S. Second National HIV Communication Survey. Pretoria, JHHESA. (jhhesa.org/sites/default/files/.../03_National_Communication_ Survey.pdf) [Last accessed on 2014 Apr 25].

45. Lester RT, Ritvo P, Mills EJ, Kariri A, Karanja S, Chung MH, et al. Effects of a mobile phone short message service on antiretroviral treatment adherence in Kenya (WelTel Kenya1): A randomised trial. Lancet 2010;376:1838-45.

46. Foss AM, Hossain M, Vickerman PT, Watts $\mathrm{CH}$. A systematic review of published evidence on intervention impact on condom use in subSaharan Africa and Asia. Sex Transm Infect 2007;83:510-6.

47. Weller SC, Davis K. Condom effectiveness in reducing heterosexual HIV transmission. Cochrane Database of Systematic Reviews. CD003255. Cochrane Database of Systematic Reviews2007, Issue 4.(http://apps. who.int/rhl/hiv_aids/cd003255/en/) [Last accessed on 2014 Apr 25].

48. Saphonn V, Sopheab H, Sun LP, Vun MC, Wantha SS, Gorbach PM, et al. Current HIVIAIDS/STI epidemic: Intervention programs in Cambodia, 1993-2003. AIDS Educ Prev 2004;16:64-77.

49. Mehendale SM, Gupte N, Paranjape RS, Brahme RG, Kohli R, Joglekar N, et al. Declining HIV incidence among patients attending sexually transmitted infection clinics in Pune, India. J Acquir Immune Defic Syndr 2007;45:564-9.

50. Weller S, Davis, K. Condom Effectiveness in Reducing Heterosexual HIV Transmission. Cochrane Review. In: The Cochrane Library. Chichester, UK: John Wiley \& Sons, Ltd. 2003 Issue 4.

51. Drew WL, Blair M, Miner RC, Conant M. Evaluation of the virus permeability of a new condom for women. Sex Transm Dis 1990;17: 110-2.

52. Shane B, Herdman C. The female condom: Significant potential for STI and pregnancy prevention. Outlook. 2006;22:40-2.

53. Vijayakumar G, Mabude Z, Smit J, Beksinska M, Lurie M. A review of female-condom effectiveness: Patterns of use and impact on protected sex acts and STI incidence. Int J STD AIDS 2006;17:652-9.

54. Hatzell T, Feldblum PJ, Homan RK, Gmach RD. The female condom: Is "just as good" good enough? Sex Transm Dis 2003;30:440-2.

55. French PP, Latka M, Gollub EL, Rogers C, Hoover DR, Stein ZA. Useeffectiveness of the female versus male condom in preventing sexually transmitted disease in women. Sex Transm Dis 2003;30:433-9.

56. Auvert B, Taljaard D, Lagarde E, Sobngwi-Tambekou J, Sitta R, Puren A. Randomized, controlled intervention trial of male circumcision for reduction of HIV infection risk: The ANRS 1265 Trial. PLoS Med 2005;2:e298.

57. Bailey RC, Moses S, Parker CB, Agot K, Maclean I, Krieger JN, et al. Male circumcision for HIV prevention in young men in Kisumu, Kenya: A randomised controlled trial. Lancet 2007;369:643-56.

58. Gray RH, Kigozi G, Serwadda D. Male circumcision for HIV prevention in men in Rakai, Uganda: A randomised trial. The Lancet 2007;369:657-66.

59. Kong $X$. Long term effects of male circumcision on HIV incidence and risk behaviors during post trial surveillance in Rakai, Uganda. CROI. (http:// www.hivandhepatitis.com/2011_conference/croi2011/docs/0311_2010c. html) [Last accessed on $2014 \mathrm{Apr} 25$ ].

60. WHO and UNAIDS.WHO and UNAIDS announce recommendations from expert meeting on male circumcision for HIV prevention. 2007, 28 ${ }^{\text {th }}$ March). Accessible at: http://www.who.int/hiv/mediacentre/news68/en/ index.html [Last accessed on 2014 Apr 25].

61. Baeten JM, Donnell D, Kapiga SH, Ronald A, John-Stewart G, Inambao M, et al. Male circumcision and risk of male-to-female HIV-1 transmission:
A multinational prospective study in African HIV-1-serodiscordant couples AIDS 2010;24:737-44.

62. UNAIDS/WHO/SACEMA. Male circumcision for HIV prevention in high HIV prevalence settings: What can mathematical modeling contribute to informed decision making?(2009). Accessible at: http://www.ncbi.nlm.nih. gov/pmc/articles/PMC2731851/ [Last accessed on 2014 Apr 25].

63. Cohen MS, Chen YQ, McCauley M, Gamble T, Hosseinipour MC Kumarasamy N, et al. Prevention of HIV-1 infection with early antiretroviral therapy. N Engl J Med 2011;365:493-505.

64. Fleming DT, Wasserheit JN. From epidemiological synergy to public health policy and practice: The contribution of other sexually transmitted diseases to sexual transmission of HIV infection. Sex Transm Infect 1999;75:3-17.

65. Wasserheit JN. Epidemiological synergy. Interrelationships between human immunodeficiency virus infection and other sexually transmitted diseases. Sex Transm Dis 1992;19:61-77.

66. Wasserheit JN. Epidemiological synergy. Interrelationships between human immunodeficiency virus infection and other sexually transmitted diseases. Sex Transm Dis 1992;19:61-77.

67. Holmes KK, Sparling P. Sexually Transmitted Diseases, $4^{\text {th }}$ Edition New York: McGraw Hill; (4 ${ }^{\text {th }}$ Edn), 2008;1958-76.

68. Sobngwi-Tambekou J, Taljaard D, Lissouba P, Zarca K, Puren A, Lagarde E, et al. Effect of HSV-2 serostatus on acquisition of HIV by young men: Results of a longitudinal study in Orange Farm, South Africa. J Infect Dis 2009;199:958-64.

69. Barnabas RV, Wasserheit JN. Riddle of the Sphinx revisited: The role of STDs in HIV prevention. Sex Transm Dis 2009;36:365-7.

70. Cardo DM, Culver DH, Ciesielski CA, Srivastava PU, Marcus R, Abiteboul D, et al. A case-control study of HIV seroconversion in health care workers after percutaneous exposure. Centers for Disease Control and Prevention Needlestick Surveillance Group. N Engl J Med 1997;337:1485-90.

71. Otten RA, Smith DK, Adams DR, Pullium JK, Jackson E, Kim CN, et al. Efficacy of postexposure prophylaxis after intravaginal exposure of pigtailed macaques to a human-derived retrovirus (human immunodeficiency virus type 2). J Virol 2000;74:9771-5.

72. Shaffer N, Chuachoowong R, Mock PA, Bhadrakom C, Siriwasin W, Young NL, et al. Short-course zidovudine for perinatal HIV-1 transmission in Bangkok, Thailand: A randomised controlled trial. Bangkok Collaborative Perinatal HIV Transmission Study Group. Lancet 1999;353:773-80.

73. Cardo DM, Culver DH, Ciesielski CA, Srivastava PU, Marcus R, Abiteboul D, et al. A case-control study of HIV seroconversion in health care workers after percutaneous exposure. Centers for Disease Control and Prevention Needlestick Surveillance Group. N Engl J Med 1997;337: 1485-90.

74. Harrison LH, Do Lago RF. Post-sexual-exposure chemoprophylaxis (PEP) for HIV: A prospective cohort study of behavioral impact [Abstract 225]. Presented at the $8^{\text {th }}$ Conference on Retroviruses and Opportunistic Infections, Chicago, Illinois: 2001. February 4-8.

75. Coetzee D, Hildebrand K, Boulle A, Maartens G, Louis F, Labatala V, et al. Outcomes after two years of providing antiretroviral treatment in Khayelitsha, South Africa. AIDS 2004;18:887-95.

76. Crum NF, Riffenburgh RH, Wegner S, Agan BK, Tasker SA, Spooner KM, et al. Comparisons of causes of death and mortality rates among HIVinfected persons: Analysis of the pre-, early, and late HAART (highly active antiretroviral therapy) eras. J Acquir Immune Defic Syndr 2006;41: 194-200.

77. Quinn TC, Wawer MJ, Sewankambo N, Serwadda D, Li C, WabwireMangen $F$, et al. Viral load and heterosexual transmission of human immunodeficiency virus type 1. Rakai Project Study Group. N Engl J Med 2000;342:921-9.

78. Attia S, Egger M, Müller M, Zwahlen M, Low N. Sexual transmission of HIV according to viral load and antiretroviral therapy: Systematic review and meta-analysis. AIDS 2009;23:1397-404

79. Donnell D, Baeten JM, Kiarie J, Thomas KK, Stevens W, Cohen CR, et al. Heterosexual HIV-1 transmission after initiation of antiretroviral therapy: A prospective cohort analysis. Lancet 2010;375:2092-8.

80. Del Romero J, Castilla J, Hernando V, Rodríguez C, García S. Combined antiretroviral treatment and heterosexual transmission of HIV-1: Cross sectional and prospective cohort study. BMJ 2010;340:c2205. 
81. Karim QA, Karim SS, Frohlich JA. Effectiveness \& safety of tenofovir gel, an antiretroviral microbicide, for prevention of HIV infection in women. Sci. 2010;329:1168-74.

82. Grant RM, Lama JR, Anderson PL, McMahan V, Liu AY, Vargas L, et al. Preexposure chemoprophylaxis for HIV prevention in men who have sex with men. N Engl J Med 2010;363:2587-99.

83. Thigpen MC, Kebaabetswe PM, Smith DK. Daily oral antiretroviral use for the prevention of HIV infection in heterosexually active young adults in Botswana: Results from the TDF2 study. $6^{\text {th }}$ International Conference on
HIV Pathogenesis, Treatment and Prevention. July 17-20, 2011, Rome, Italy. Abstract WELBC01.

How to cite this article: Chattu VK. Role of biomedical and behavioral interventions and their evidence in prevention of HIV infection: A literature review. Int J Med Public Health 2014;4:324-30.

Source of Support: Nil, Conflict of Interest: None declared.

\section{Author Help: Online submission of the manuscripts}

Articles can be submitted online from http://www.journalonweb.com. For online submission, the articles should be prepared in two files (first page file and article file). Images should be submitted separately.

\section{1) First Page File:}

Prepare the title page, covering letter, acknowledgement etc. using a word processor program. All information related to your identity should be included here. Use text/rtt/doc/pdf files. Do not zip the files.

\section{2) Article File:}

The main text of the article, beginning with the Abstract to References (including tables) should be in this file. Do not include any information (such as acknowledgement, your names in page headers etc.) in this file. Use text/rtf/doc/pdf files. Do not zip the files. Limit the file size to $1024 \mathrm{~kb}$. Do not incorporate images in the file. If file size is large, graphs can be submitted separately as images, without their being incorporated in the article file. This will reduce the size of the file.

3) Images:

Submit good quality color images. Each image should be less than $\mathbf{4 0 9 6} \mathbf{~ k b ~ ( 4 ~ M B ) ~ i n ~ s i z e . ~ T h e ~ s i z e ~ o f ~ t h e ~ i m a g e ~ c a n ~ b e ~ r e d u c e d ~ b y ~ d e c r e a s i n g ~}$ the actual height and width of the images (keep up to about 6 inches and up to about $1800 \times 1200$ pixels). JPEG is the most suitable file format. The image quality should be good enough to judge the scientific value of the image. For the purpose of printing, always retain a good quality, high resolution image. This high resolution image should be sent to the editorial office at the time of sending a revised article.

4) Legends:

Legends for the figures/images should be included at the end of the article file. 